\title{
Critical Analysis of Granting Interim Measures in Arbitration in the Context of Jordan Arbitration Law No. 16. 2018
}

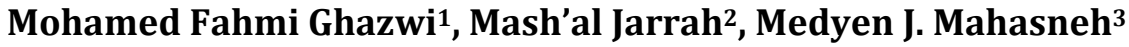 \\ ${ }^{1}$ Faculty of Law, Al Zaytoonah Jordan University, Amman, Jordan \\ ${ }^{2}$ Faculty of Law, Amman Arab University, Amman, Jordan \\ ${ }^{3}$ Faculty of Law, Al Isra University, Amman, Jordan \\ Email:m.ghazwi@zuj.edu.jo, Mashal.jarrah@aau.edu.jo, medyan.jamal@iu.edu.jo
}

How to cite this paper: Ghazwi, M. F., Jarrah, M., \& Mahasneh, M. J. (2019). Critical Analysis of Granting Interim Measures in Arbitration in the Context of Jordan Arbitration Law No. 16. 2018. Beijing Law Review, 10, 1100-1115.

https://doi.org/10.4236/blr.2019.104059

Received: October 22, 2018

Accepted: September 27, 2019

Published: September 30, 2019

Copyright $\odot 2019$ by author(s) and Scientific Research Publishing Inc. This work is licensed under the Creative Commons Attribution International License (CC BY 4.0).

http://creativecommons.org/licenses/by/4.0/

\section{Open Access}

\begin{abstract}
Current arbitration laws and rules assume that national court and the Tribunal coexist together in terms of their granting of interim measures particularly in international cases of arbitration. This paper attempted the stance of Jordan Arbitration Law 2018 on granting interim measures during arbitration by providing a discussion of the entity in authority in the country that grants such measures. The study used a major approach namely qualitative based on exploratory method with minimal usage to comparative analysis in order to benefit from those states in the point of granting of interim measures. Data were gathered from libraries and published reports and the research found that the major power that grants interim measures in Jordan is the National Court with the least authority held by the tribunal-a power that should be enumerated in the arbitration agreement.
\end{abstract}

\section{Keywords}

Arbitration, Interim Measures, Arbitral Tribunal, National Court, Jordan

\section{Introduction}

In a commercial transaction, parties to the contract often opt for arbitration as opposed to litigation for different reasons when it comes to resolving disputes. The primary reason behind this inclination lies in the expedient process in arbitration although it is notable that issuing a final award may take quite some time but not as long as it takes in court. Therefore, in ensuring interim measures, it is necessary to govern the relationship conditions that go on during the arbitration 
proceedings to make way for the final award and resolve issues that are linked to the provisions (Kohler \& Stucki, 2004). In this regard, interim measures are generally referred to as procedural mechanisms that the courts and arbitral tribunals utilized to resolve expedient matters at the initial phase of the proceedings as well as the later phases to ensure that the issue of dispute is safeguarded.

In the current times, the majority of arbitration laws and rules assume that National Court along with the Tribunal coexists in terms of their authority to grant interim measures in the realm of international arbitration cases. Regardless of this fact, the main issue when it comes to interim measures is which entity has the authority to grant them-the tribunal, the court or both?

In this background, the present paper examines the legal position of interim measures granting in arbitration in the Jordanian legal system. In fact, the parties' demand for interim measure may cause them to face complex issues, both tactical and legal and this necessitates them taking matters into consideration. The first of these issues is that the party seeking for interim measures may be confronted with the issue as to the entity that has the authority to grant interim measures and this is related to the following two questions; 1) Who has the authority to grant interim measures (the tribunal or the court)? 2) Do any of the entities possess exclusive authority or does the seeking party have the prerogative as to who to request the interim measure from?

The Jordan Arbitration Law No. 16 of 2018 explicitly provides that in an arbitration agreement, it is not compatible for a party to seek provisional/conservatory measure (before/during) arbitral proceedings from a Judge of Summary Matters according to the Law of Civil Procedures. Moreover, such measure may be withdrawn likewise, indicating that the arbitration parties hold no right to opt for an interim measure before a Judge of Summary Matters based on the mentioned law. However, the legislator can grant the parties to take the recourse of the Tribunal to grant such measures during the arbitral proceedings, if it is included in the agreement as explicitly stated in Article 23/a of the Jordan Arbitration Law No. 16 of 2018. The law, according to Article 13, states that two arbitrating parties may agree to empower the arbitral tribunal to order each of them, by its own initiative or when requested, to take interim or conservative measures if required by the disputed subject-matter. Also, the tribunal may require any of the parties to provide security for the expenses incurred by such measures. The Law enumerates instructions of provisions granted by the Tribunal, if the party so ordered does not adhere to the measures as indicated in Article 23/b, which states that if the ordered party fails to execute, then the arbitral tribunal may be requested by the other party to grant the authority to take the necessary procedures in order to execute his right to proceed his application to a competent court for enforcement order.

According to the law discussed above, the authentic authority that grants interim measures is the National Court as opposed to the arbitral tribunal although the arbitral parties can decide not to opt for interim measures before the nation- 
al court as clarified in Article 13. The article provides the incompatibility of the parties to the arbitration to request for such measures.

More importantly, the legislator may not be able to manage two issues faced by the parties to arbitration when requesting interim measures before the court. To clarify, first, the lack of emergency arbitrator and arbitral tribunal would make the national court the only authority that the party can turn to for recourse (in particular, the Judge of Summary Matters). The legislator should take Article 109/1 of Civil Procedures Law 2006, into consideration that stresses the on the request of the litigant, prior to case subject handling, for the court to issue the decision under which condition that the applications are submitted together or separately; a lack of jurisdiction, b) an arbitration clause, c) case is already settled, d) lapse of time, e) untrue service papers. Additionally, according to Article 152/1 of Civil Procedures Law 2006, after the decision has been made to inflict precautionary sequestration, denial of mobility freedom or other precautionary procedures should be taken prior to lodging the case-the application has to submit the case to declare his right eight days from the day following the decision issuance date. If he fails to do so within the required period, the issued decision will not be considered as issued. The Chief Judge, delegating the Summary Action Judge must take the necessary procedures for the nullification of decision, meaning that if the case is brought in front of an ordinary court and the judge issues the request for interim measures, the sought party has to bring an action prior to the court within eight days from the issuance of such measures. The question that bears introspection is whether this term applies in arbitration.

For instance, prior to starting the arbitral proceedings (requiring a month to initiate), a party to such arbitration should be granted interim measures before a Judge of Summary Matters as declared in the Civil Procedures Law 2006. The arbitral tribunal has to be initiative within eight days from the interim measures issuance, or the bringing of the action in front of the court. Due to the unfeasibility of forming arbitral tribunal within this period, the only recourse by the sought party is to bring an action in front of the national court. The other party can nevertheless refer to Article 109 of the Civil Procedure Law 2006 to drop the case or appeal the order from the Appeal Court by forwarding the original copy of the arbitration agreement, after which the latter will drop the order.

Article 23/a states the possibility of the parties empowering the arbitral tribunal to grant interim measures during the arbitration proceedings. At the same time, the national court is given the same power during such proceedings and the argument in this case is the confusion caused as to which entity to seek the measures from (the national court or the tribunal). The two articles (Article 13/1 and 23/a) stipulate that the national court and tribunal have the discretion to order interim measures during the arbitral proceedings sans clarifying the interim measures types that they can issue - this also leads to the confusion of the seeking party. On the basis of the above, the question arises as to whether the national court has a participative or supportive role. 


\section{The Meaning, Nature and Purpose of Interim Measure}

In international arbitration, the interim measure's status cannot be stressed enough - it is dire to protect arbitrational stakes through interim measures (Association for International Arbitration, 2007). The agreement is such that if the order of interim measures is not granted or if they are made unenforceable, then the final award loses its meaning (Lemenez \& Quigley, 2009). The defendant party may resort to destruction and hiding of evidence, removal of goods/assets from the enforcement place without the interim measures, and this would render the arbitral award no better than Pyrrhiz Victory. In recent times, researchers advocate the importance of interim measures in correspondence to the number of parties' demands that seek them and highlight the possibility of even increasing requests in the future (Pryles \& Moser, 2007).

Interim measures come in several forms and they are referred to in different terms; for example, the UNCITRAL Model Law Rules of Arbitration describes interim measures as interim measures of protection. Notably, the above UNCITRAL terminology is still consistent as Article 9 has not made modifications to the term and still refers to it as interim measures of protection.

Furthermore, the ICC Rules describes them as interim or conservatory measures, or measures provisoires ou conservatoirs. In this regard, the description of interim measures has become obsolete in many laws of national arbitration.

As with its changing terminology name, interim measures categorizations are also varied. Three general categories of such measures exist; a) those facilitating arbitral proceedings conduct, b) those that safeguard loss/damage, and specific sets of situations until the settlement of dispute, and c) those that facilitate the enforcement of final arbitral award (Kaminskiene, 2010).

Added to the above, three general categorizations of interim measures were presented by Mr. Wirth. First, interim measures are used to maintain the status quo to ensure effective award enforcement. This covers procedures of conservation of goods, deposit with third person, sales of perishable items, opening of banker's credit, machinery or work's use and maintenance, and security deposit placement in instances of expected damages. The second category is used to balance the legal relationships between the involved parties to the proceedings. This covers requiring compliance towards contractual duties and preservation of proprietary information and trade secrets. The third category protects evidence for its availability in the next phase of the proceedings (Wirth, 1999).

After the new relief forms were introduced, Redfern claimed that one should not think of interim measures as related to closed categories. He laid stress on the fact that the categories have two common features; 1) their purpose is basically to be provisional or temporary and thus, they do not act as the final resolution of the dispute, and 2) interim relief applications are often made urgently, and if they are not granted, damages incurred may not be reversed (Redfern, 1995).

In other words, the interim measure can be provisional/temporary prior to the 
issuance of award that conclusively determines the dispute (Wirth, 1999). This can be exemplified by the rule in the Albania Code of Civil Procedure (CCP) 1996 Article 211, stating that if the claim is rejected by a tribunal or competent court, the respective authority entities must lift the interim measures and such lifting is done after the irreversible decision is finalized. Along a similar line of example, the Hungarian Arbitration Act 1994, Article 26 stated that the decision of the interim measures remains effective until its revocation by the new decision of the Tribunal or until the issuance of the Tribunal award.

Litigation and arbitration practitioners understand the practical importance that the interim measures protection represent and on the basis of the measures' definition, the following features can be discerned; they are temporary in nature and not a representation of the final dispute resolution, they are applied in instances of real danger of irreversible harm if not protected through interim measures.

The purpose behind interim measures is primarily the preservation of the ability of the court to pass a meaningful decision as such measures prevent damages from incurring prior to the final judgment. Hence, the court holds the authority to grant suitable relief when it passes judgment following the procedural rights due to the parties (Donovan, 2003). The standards of issuance of interim measures in proceedings vary but they generally cover the elements of urgency, imminent or irreversible harm, and maintenance of status quo (Schreuer, 2001). Stated clearly, an interim measures is a remedy or a relief that safeguards the rights of the parties to a dispute before the final resolution is reached. In other words, interim measures are temporary and not permanent in nature (Webster \& Buhler, 2014).

Therefore, an arbitral tribunal has the authority to grant the required interim measures that relates to the disputed issue based on the fulfillment of three requirements; 1 ) a serious probability of the requesting party will succeed based on merits, enough evidence of harmful risk on the requesting party's rights, and harm resulting from the interim measure does not significantly outweigh the party's inclination to steer clear from the damage meant to be avoided.

\section{The Types of Interim Measures That Arbitral Tribunal Is Authorized to Grant}

The arbitral tribunal's power to order interim measures have to be backed by applicable procedural law: the law selected by the parties or in its absence, the law of arbitration in place. Moreover, the major rule sets provided for arbitral provisions explicitly empower the arbitrator to order interim measures (Roth, 2012). In the field of arbitration practice, tribunals generally use several interim measure types to protect the parties seeking them. The general categories of provision measures ordered by arbitrators are of four types.

The first category of interim measures facilitates the arbitral proceedings with the inclusion of order to preserve evidence needed for the case outcome, order of inspection of specific goods, property, machinery, site or documents, order that 
prevents public statements in breach of confidentiality obligations or others that are likely to aggravate the dispute, anti-suit injunctions that prevent the party from the pursuant of litigation that is external to the contractual arbitral forum and breaches the arbitration agreement of between the parties (Roth, 2012).

The second category preserves and restores the status quo or calcifies the contractual relations of the parties, while the arbitral proceedings are pending. They cover an order that prevents the disposition of the disputed object, order to deposit the disputed goods under some individual's custody, and order to sell perishable goods and to place the sale proceeds in an escrow account, an order to require a contractor to continue with construction works/or compel the owner to continue his installment payments if required, to an escrow account that is monitored by the arbitral tribunal, an order to require a manufacturer's continuance of supplying a distributor, or the latter to continue selling the product of the former, an order refraining a party from proceeding to manufacture or sell products that form the disputed patent rights, order to refrain from using disputed trademarks, order granting authority to a party to cease or suspend from performing other obligations from the contract, order that prevents a party from calling upon a bank guarantee or returning the same in an unjustified way, order that suspends the corporate resolution effect, order that ensures the individual has no authority to act on behalf of an another for the time being, and order that guarantees the enjoyment of the claimant of the rights, like voting shares that adhere to the agreement of the shareholder. Aside from the above orders are the order to provide the company records for the management and performance of company, order that drives a party to refrain from undertaking specific activities that are not aligned with the daily course of business, and an order that appoints a neutral manager to manage the activities of the company or part of it (Voser, 2007).

The third category of interim measures is one that facilitates the enforcement of future arbitral award and this includes order that freezes the party's assets, an order that prevents the moving of assets or the dispute subject-matter out of jurisdiction, an order that directs the provision of the party of with a bank guarantee, an order for separating a sum of money for the security of payment of the applicant's monetary claim in case the respondent becomes insolvent (because of the extent allows under the legislation of applicable insolvency) (Berg, 2009). The last category of measures are orders for security costs like an order to ensure that in case the claimant loses the case and the legal costs are awarded to the winning party, funds will be available to satisfy the award.

It is noteworthy that in case the arbitrator could efficiently order the interim measures provided by the court, there is no need or justification for court applications by the parties to the arbitration. However, owing to the limited jurisdiction of the arbitrator, the assistance of the court is called for. First, the limitation in arbitrator jurisdiction is linked to the nature of the arbitral process in that the arbitrator's power stems from the arbitration agreement. It is contract that binds the parties to its and does not affect third parties. Second, the limitation lies in 
the lack of enforcement power of the arbitration when third parties are concerned.

When taken into account, the limitations highlight the importance of access to courts for specific kinds of interim relief in arbitration. Despite the provision of arbitration-granted interim relief, there will be one step added in terms of the enforcement procedure. It is necessary for the court to grant the arbitrator with the permission to enforce an order and this may take time. However, the limitation is not confined to speed and time but also covers administrative details of arbitration, for instance, the lack of permanent arbitral tribunal that international commercial arbitrations can be forwarded to, necessitating the need to establish tribunal for every arbitration request and again this is a slow process. In this case, is no available body to grant interim protection measures so long as the file has not been forwarded to the arbitrator. Based on practice, the interim measures of protection are often required mostly prior to the proceeding of the case to trial, and this holds true for arbitration. The highest requirement for provisional remedies occurs prior to the establishment of the tribunal.

\section{The Competent Organ to Order Interim Measure}

The critical question relating to interim measures in the context of arbitration is the authority to order the interim measures, is it tribunal, the court or both.

Interim relief in arbitration is an interface between private dispute settlement and the ordinary court. It is one of these aspects of arbitration procedure that cannot escape court interference. The arbitrator has no power to enforce his orders. Additionally, as the effectiveness of an interim measure of protection depends, in the end, on its enforceability, court support may be needed (Schaefer, 1998). Arbitral tribunals usually have powers to order interim orders of protection (Lew, Mistelis, Kröll, \& Kröll, 2003). Examples of orders which may be ordered include measures to preserve evidence and regulate the relationship of parties during proceedings. Measures may also be taken for the payment of money or for security for costs.

The purpose of such measures is generally to preserve the rights of the parties and the subject matter in dispute pending the determination of the substantive matter. This is to ensure that the final order of the tribunal will be capable of being enforced and to prevent foisting a state of helplessness on the tribunal (Born, 2016). Interim measures need to always be issued by the court if the tribunal itself has not been established.

In addition, interim measures may need to be ordered by the court for several other reasons. For example, the New York Convention requires the finality of the arbitration award for the sake of enforcement in member states. (PDF) Issuing Interim Measures in Arbitration in the Kingdom of Saudi Arabia.

Apart from that, interim measures are not final awards. Therefore, it is better to seek a court decision here in order to enforce it in foreign states. Furthermore, during arbitration proceedings, the court may be requested to issue provisional measures orders. In addition, in some states' arbitration rules, the tribunals in 
UAE cannot issue interim measures orders. Instead, such measures must be sought through the state court (Masadeh, 2013).

\section{a) The Authority of an Ordinary Court to Grant Interim Measures}

According to the Jordan Arbitration Law 2018 Article 23 (a), subject to Article (13) of the law, two arbitrating parties may consent to the empowerment of arbitral tribunal to order either one of the parties, by their initiative or request, to accept interim/conservative measures if required in relation to the disputed issue, and it may require any of the party to do the following; 1) to provide security that covers the measures' expenses.

Added to the above, Article (13) also stipulates the incompatibility to an arbitration agreement if a party requests, prior to or during arbitral proceedings, from a Judge of Summary matters, a provisional/conservative measure be taken according to the Law of Civil Procedures, and this measure can be withdrawn likewise.

According to the above, legislators can turn to arbitral tribunal or ordinary courts for interim measures during arbitration if both are granted power simultaneously. Nevertheless, the ordinary court has the original jurisdiction over the arbitral tribunal. This has been disputed by scholars as there is the possibility of issues arising as to whether seeking recourse from courts could mean waiving the arbitration agreement. This may also lead to the court's refusal to assist the parties to the arbitration.

\section{b) The Power of Arbitral Tribunal to Grant Interim Measures}

The core provision stipulated by the Jordan Arbitration Law 2018 is Article 23 as mentioned above, which indicates the legislator's non-granting of power to the tribunal the power when it comes to interim measures without the mention of the same in the arbitration agreement.

The legislator becomes at fault if it forbids the tribunal to grant such measures as the latter should be the authentic authority as opposed to the court. This is because the tribunal has viewed the case, something that the court is prohibited to do by law. Additionally, the tribunal is more familiar with the case merit compared to the Judge of Summary Matters who does not hold the authority to view it. Hence, the tribunal should properly issue the measures. The question arises as to how the arbitrator can make decisions on a case when he is not allowed to grant interim measures.

In cases, where the arbitral parties explicitly provide in the agreement that the tribunal has power to grant interim measures during the process of arbitration, the situation will be such that; a party refrains from waiving his right to arbitration by taking recourse from the national court and second, a national court may grant the measures even in the face of an arbitration agreement.

\section{Interim Measures under Foreign National and International Laws}

In this part, the researcher will show the practice of granting interim measures in arbitration under the Model Law 2006, Malaysian Arbitration Act 2005 and In- 
ternational Singaporean Act 1944 in comparison with Jordan Arbitration law 2018

a) The Practice of Granting Interim Measures under the Model Law 2006

The adoption of the UNCITRAL Model Law has been extensive throughout the years involving over 60 jurisdictions (UNCITRAL, 2010) including Egyptian jurisdiction, upon which the basis of Jordan Arbitration Law 2018 is founded upon. The Model Law is built on free-choice approach, where the arbitration party may choose to apply to the court or arbitral tribunal to seek the interim measure of protection the court can easily be accessed in this case, with no need for the party to seek permission from the arbitrator.

The law provides that the tribunal may grant interim measures when requested by the parties to it under the condition that a contrasting agreement was entered into (UNCITRAL, 2010). It refers to interim measure as a measure that is temporary in the form of an award or otherwise sought before the final decision is made to the dispute in order to realize any of the following; 1) maintain and restore the status quo in the face of pending dispute, 2) prevent harm to the arbitral process, 3) maintains the preservation of assets to the dispute, and 4) maintains the preservation of evidence to the dispute. Furthermore, the Model Law stipulates that national courts should enforce interim measures and allow applications for them (UNCITRAL, 2010).

Interim relief can be obtained only when the applicant indicates irreversible damage that outweighs harm to the opposing party, and a possibility exists that the applicant will succeed in his claim (UNCITRAL, 2010). According to a commentator, such standard calls for the party seeking relief to show imminent danger/serious prejudice implied by the urgency, and that such risk will irreversible harm his legal interests that monetary award may not be enough for compensation because of the nature of harm (Wang, 2002). Hence, the standard covers a test of balance that shows if the benefit to the applicant outweighs the prejudicial effect on the party against it is directed at. The tribunal has discretionary power to apply or refrain from applying the standard where the applicant only attempts at finding evidence (Alan, 1995) It is noteworthy that the Model Law had allowed the tribunal to award required measures when called for (Wong, 2004). However, UNCITRAL revised the Model Law standard to clarify carrying out a survey concerning various courts' power so that arbitration is supported.

Specifically, the Model Law states that a party to the arbitration can make an ex-parte application for interim measure if the risk of the other party will invalidate the measure's purpose. Such ex-party order has a limit of twenty days and it is not subject to court enforcement. However, the tribunal may issue an interim measure if it provides the opposing party with notice prior to the expiry of the twenty-day period. Another requirement involves the application to ex-parte orders, in which case, the tribunal may require the applicant to provide interim security measure and to post security for an ex-parte order under the condition 
that the tribunal does not deem it to be unsuitable or unnecessary (UNCITRAL, 2010).

The Model Law does not establish procedures for pre-tribunal relief (Ferguson, 2003). According to one commentator, the Model directs parties by omission to seek interim relief from national courts prior to the establishment of the tribunal (Lew, 2009).

Evidently, the Model Law did not address accurately stipulate the timing and that it could take up to 60 days to form an arbitral of three, unless agreed upon, as every party has 30 days to appoint an arbitrator following the request, and two arbitrators have 30 days to choose a third one. Specifics are not laid down by the Model Law as to the selection timing of a single arbitrator, specifically procedures pertaining to the arbitration of the final arbitration award.

As covered by the UNCITRAL rules, several awards may be issued by the tribunal on various issues at different points of time. When requested, the tribunal, based on Article 26 may grant interim measure that requires the party to do any of the following; 1) maintain the situation as is until the final resolution of the dispute is reached, 2) take action or refrain from taking action that could bring about irreversible harm to the arbitral process, 3) maintain assets required for the award satisfaction, or 4) maintain evidenced preservation. Generally, the tribunal may grant an interim measure only when the seeking party has illustrated irreversible harm and reasonable justification for success on the merits. Based on the rules, applications to a judicial authority is a must in order to obtain interim relief (UNCITRAL, 2010).

In addition, contrasting to ex-parte procedure that was laid down by the Model Law, it is explicitly mentioned in the rules that the parties should communicate to the tribunal with all other parties but they failed to establish a pre-tribunal relief and to stipulate distinct expedited procedures. However, the Rules do set time periods in terms of response to the arbitration notice and the tribunal appointment and they do grant the tribunal with discretionary powers when it comes to the proceedings timings (UNCITRAL, 2010).

On the other hand, the Jordan Arbitration Law 2018 grants authentic power to the national court to provide interim measures unless the contract explicitly forgoes the same. This is in contrast to the Model Law 2006 that grants authority to both the tribunal and the court even without explicit agreement.

Evidently, no competition lies between the national court and the tribunal when it comes to interim measures as the two support each other in contrast to the Jordan Arbitration Law 2018. Legislators of both laws failed to indicate the order of authority that precedes the other between the two.

b) The practice of issuing interim measures in the context of Malaysian Arbitration Act 2005

The Jordan Arbitration Law 2018 in comparison to the Malaysian Arbitration Act 2005 in Regards to Granting Interim Measures.

In both the orders from the arbitral tribunal and the high court are deemed to be the same but the High Court holds more power when it comes to receiver 
appointment and other unspecified measures. It can be stated that this may cause ambiguity to the party that needs a measure as to which entity holds complete power to grant measures.

In addition to the above, an overlap was noted between Section 11 (1) (a), (b), (c), (d) and (f) as well as Section 19(1) (a), (b), (c) and (d), creating confusion as to the discretion of the tribunal and the authority of the country to order international interim measures during arbitral proceedings. For instance, in the Corbain Holdings Sdn Bhd v GDP Special Projects Sdn Bhd [2010] 1 LNS 1834, the plaintiff applied to the court for the orders based on Section 11 of the Arbitration Act 2005 and Order 29 of the High Court Rules 1980. The statement highlighted the evident overlap between Sections 11 and 19 of the Malaysian Arbitration Act 2005. Following fundamental principles, a concurrent jurisdiction calls for the application before the tribunal, unless countervailing factors are involved, as the role of the High Court is to reinforce arbitration and in so doing, section 11 of the Malaysian Arbitration Act 2005 remains inapplicable during the proceedings. This indicates that the competent court has no authority to grant interim measures during the attribution-a law that clashes with Section 11 of the Malaysian Arbitration Act 2005 as the latter gives authority to grant interim measures prior to and during the process of arbitration. The Judgment of the case.

"It has to be said that the reliance on Order 29 and the inherent jurisdiction of this court was an alternative basis, and the Plaintiff did not actively pursue its case on this basis, but more on Section 11 of the Arbitration Act, 2005. This preliminary position has to be emphasized since it encapsulates the principles of party autonomy and minimalist intervention by the courts of law. From this basic principle, a number of subsidiary principles arise which have a direct bearing on the outcome of these cases".

With regards to the standards of granting international interim measures by the tribunal or High Court, this is not addressed by the Malaysian Arbitration Act 2005. This was aimed at avoiding the element of acting in bad faith while requesting for such measures. As for the overlapping provision of Section 20 (Article 19 of the Model Law), each party is required to be treated equally and given a fair and reasonable chance of presenting the case, with the dominant view being that the tribunal lacks the power. The right approach is the parties' recourse to the High Court for wider exercise of power. Hence, the power overlap between the High Court and the Tribunal ensures the existence of conflict, where a party opts for the High court, while another one opts for the tribunal. The possibility exists of one party attempting to prevent the arbitration by taking the other party to court or to urge the court to enforce its view on arbitrators.

Additionally, the Malaysian Arbitration Act 2005 failed to address the issue of whether the Tribunal possesses the power to grant measures on an actual ex parte application (without notifying the other party (Davidson \& Rajoo, 2006). Here, the question arises as to which authority holds the responsibility of granting such measure. Also, if this application is acknowledging, it would clash with 
Section 37(1) (iii) that states the party may set aside the award by requesting the competent court if the party has not provided an actual notice of the arbitration.

The Malaysian Arbitration Act 2005 did not stipulate the granting of measures when it comes to a third party, who is not a party to the arbitration agreement and here, the question arises as to the what mechanism to use and which body has the authority of granting measures.

The Malaysian Arbitration Act 2005, Section 11 (2) stats that the international interim measure application that is ruled by the tribunal but later applied to the High Court, the High Court will refuse to hear such application for international interim measures as this would seem unjust since each other holds different views and it will reach a decision based on them. In other words the Malaysian Arbitration Act 2005 does not allow the seeking party to apply the same application twice to another authority and no appeal can be applied on the final decision. The Act 2005 provides both authorities the power to grant international interim measures when arbitrating, with the party seeking interim measures having only one chance to apply from both authorities. This puts the seeking party in a difficulty as to which authority to apply for.

On the basis of the above discussion, the arbitral parties have the right to request for interim measures to the High Court or the Tribunal-in the former, it has to follow the law and agreement that govern the proceedings and the competent court's national law.

On the basis of the interviews of judges and arbitrators conducted in Malaysian High Court, the research revealed that the judges and arbitrators are in mutual agreement of the competent court's side-by-side function with the tribunal to support arbitration. The competent court has the right to support the tribunal but not to usurp and undermine the power of the arbitrator. The court can also assist the arbitral process to preserve its integrity. In this regard, the premise that of breaching of party autonomy principle is not applicable as the High Court intervention is geared towards supporting the process of arbitration. But several measures that are beyond the power of the tribunal, like the interim measure's granting against third party, also exist. Such measures cover the appointment of the receiver and the acquisition of the disputed sum under the jurisdiction of the High Court, or the conferring of a Mereva injunction that calls for the force and service of a third party.

In addition to the above, the awards provided by the two authorities may be identical in nature but they have different functions. This can be exemplified by one of the arbitrators in Malaysia in the case of Cobrain Holdings Sdn Bhd v GDP Special Projects Sdn Bhd [2010] 1 LNS 1834, where it was held that a clear overlap exists between Sections 11 and 19. Following the fundamental principles, there is a concurrent jurisdiction, where the party has to apply to the tribunal first if there are no countervailing factors, as the High Court primarily supports arbitration. However, the tribunal does not have the authority to grant freezing order of receiver appointment, and the party has to apply to a competent court for it. 
As mentioned, with regards to the interim measures granting, both the High Court and Tribunal have similar authorities but in some measures like receiver selection, the Tribunal needs the Court's support as only the High Court in these cases hold the authority to do so. As such, it is evident that there are limitations to the measures of the Tribunal and its powers are only confined to those that do not concern enforcement (e.g., service construction and security of costs). It can therefore be stated that the High Court supports the Tribunal in the arbitral process as the separation of the two entities may be impossible.

In the Jordanian case, the Supreme Court decisions do not include the decisive position of granting interim measures between the National Court and Tribunal, similar to Malaysia. Therefore, the authority is granted to the Tribunal rather than the High Court despite the express power to grant such measures prior to and during the arbitration process.

c) The Practice of Granting of Interim Measures in International Singaporean Arbitration Act 1994

The domestic and international arbitrations in Singapore are viewed as distinct separate Acts, with the International Arbitration Act 1994 developed to align with the international rules governing international arbitration.

Singapore ranks one of the top countries in the world when it comes to Tribunal's handling of arbitration. According to the Singaporean International Arbitration Act 1994 (IAA), the Tribunal is authorized to make interlocutory orders (security for costs, discovery and interim preservation of property). This brings about the smooth working of arbitration through the swift dealing of interlocutory procedural matters by a single forum. Under Section 12 IAA, the Tribunal's powers cover the order for the preservation of samples for evidence, the order for interim injunctions that the domestic Tribunal lacks the authority to pass. The entire orders and directions of the Tribunals in Singapore, by the permission of the High Court, can be made enforceable, like they are court orders.

The Singapore High Court is empowered by Section 12A IAA 2010, to grant interim measures to support arbitration, wherever its seat may be. A level of limitation was included in the provision, in view of the fact that the High Court's measures are meant to assist the arbitral proceedings and should not cover evidential or procedural issues (e.g., interrogatories, security for costs or discovery, etc.). Added to this, the powers of the High Court are exercised only in cases when the Tribunal or arbitral entity do not hold the power to act or cannot effectively act at that time.

Furthermore, the High Court holds the authority to grant interim measures in specific situations as stipulated by the Singaporean International Arbitration Act 1994 Section 12 (A). For instance, although the High Court holds the power to grant interim measures, it exercises such power with caution and meticulousness. In situations that call for urgency, the High Court can grant interim measures on the request of either arbitral party but it should inform the Tribunal and 
the other party of such order. The High Court has the authority to grant interim measures, where there is no institution that could do (e.g., arbitral institution) as stipulated on sub-section 2.

On the basis of the above, the Singaporean International Arbitration Act 1994 provides extensive power to the Tribunal when it comes to granting interim measures, while the High Court is provided with minimal power. The latter cannot grant any interim measure without giving a notice to the Tribunal and the arbitral parties in writing, and this is confined only to urgent cases. Therefore, the Singaporean International Act 1994 follows the party autonomy principle and the option of arbitration by the arbitral parties. In this regard, the High Court only aids and supports the tribunal in doing a good job as an independent authority. This is contrary to other countries that give the decisive power to the national court rather than the Tribunal.

It is explicitly provided in the International Singaporean Act 1994 that authentic power is held by the Tribunal rather than the High Court, with the latter requiring a notice from the former when its assistance is needed to grant interim measures. This indicates that the Legislator of International Singaporean Act 1994 follows the party autonomy principle.

On the contrary, the Jordanian Arbitration Law 2018, the principle of party autonomy is not considered, and as such, the authentic power is given to the National Court as opposed to the Tribunal.

\section{Conclusion}

Interim relief refers to a bridge between the resolution of private dispute and regular court and this matter forms an aspect among others of arbitration procedure that requires the intervention of the court. The arbitrator holds no authority to enforce the orders and eventually, an interim measure is only as effective as its enforceability and this calls for the court's support (Schaefer, 1998). More often than not, the Tribunals hold the authority to order interim measures that are confined to protection (e.g., orders for preserving evidence and governance of parties' relationship) throughout the proceedings.

According to the above discussion, it is evident that the authentic power to grant interim measures should be given to the Tribunal as opposed to the Ordinary Court as the Model Law 2006, Malaysian Arbitration Act 2005 and International Singaporean Arbitration Act 1994 advocate. This is unless the order is passed against a third party that is not included in the arbitration agreement, in which case the ordinary court has the authority to grant interim measures.

With regards to the Jordan Arbitration Law 2018, it is silent on the measures that both authorities can grant but it provides the authentic power to the national court rather than the tribunal when it comes to granting interim measures. Additionally, the legislator has no authority to determine which authority to apply to, the order made by the authorized institution, and whether the party can apply to the other authorities using the same application. 


\section{Conflicts of Interest}

The authors declare no conflicts of interest regarding the publication of this paper.

\section{References}

Association for International Arbitration (2007). Interim Measures in International Commercial Arbitration (p. 75). Antwerp: Maklu Publishers.

Born, G. B. (2016). International Commercial Arbitration: Cases, Materials, and Notes on the Resolution of International Business Disputes by W. Michael Reisman, W. Laurence Craig, William W. Park and Jan Paulssonm. Journal of the London Court of International Arbitration, 32, 373-376.

Davidson, W. S. W., \& Rajoo, S. (2006). The New Malaysian Arbitration Act 2005. The Malayan Law Journal, 72, 9-10.

den Berg, A. J. (ed.) (2009) International Council for Commercial Arbitration Congress series No. 14: 50 Years of the New York Convention(pp. 576-579).

Donovan, D. F. (2003). The Scope and Enforceability of Provisional Measures in International Commercial Arbitration: A Survey of Jurisdictions, the Work of UNCITRAL and Proposals for Moving Forward. In A. J. van den Berg (Ed.), International Commercial Arbitration: Important Contemporary Questions (pp. 82-83). New York: Kluwer Law International.

Ferguson, S. M. (2003). Interim Measures of Protection in International Commercial Arbitration: Problems, Proposed Solutions, and Anticipated Results. Currents: International Trade Law Journal, 12, 55.

Kaminskiene, N. (2010). Application of Interim Measures in International Arbitration: The Lithuanian Approach. Jurisprudence, 1, 243-260.

Kohler, G. K., \& Stucki, B. (2004). International Arbitration in Switzerland: A Handbook for Practitioners (p. 69). Dordrecht: Kluwer Law International.

Lemenez, G., \& Quigley, P. (2009). The ICDR'S Emergency Arbitration Procedure in Action. Dispute Resolution Journal, 63, 3.

Lew, J. D. M. (2009). Does National Court Involvement Undermine the International Arbitration Process? American University International Law Review, 24, 489-537.

Lew, J. D., Mistelis, L. A., Kröll, S. M., \& Kröll, S. (2003). Comparative International Commercial Arbitration. Kluwer Law International.

Masadeh, A. (2013). The Court's Supportive Role in Arbitration under the Law of United Arab Emirates. International Journal of Humanities and Management Sciences, 1, 129-131.

Pryles, M., \& Moser, M. (2007). Asian Leading Arbitrators' Guide to International Arbitration (p. 249). Juris Publishing, Inc.

Redfern, A. (1995). Arbitration and the Courts: Interim Measures of Protection-Is the Tide About to Turn? The Texas International Law Journal, 30, 77-78.

Roth, M. (2012). Interim Measures. Journal of Dispute Resolution, 2012, 426-435. http://scholarship.law.missouri.edu/jdr/vol2012/iss2/3

Schaefer, J. K. (1998). New Solutions for Interim Measures of Protection in International Commercial Arbitration: English, German and Hong Kong Law Compared. Electronic Journal of Comparative Law, 2, 2.

Schreuer, C. H. (2001). The ICSID Convention: A Commentary (p. 751). Cambridge: 
Cambridge University Press.

Voser, N. (2007). Interim Relief in International Arbitration: The Tendency towards a More Business-Oriented Approach. Dispute Resolution International, 1, 181-183.

Wang, W. (2002). Note, International Arbitration: The Need for Uniform Interim Measures of Relief. Brooklyn Journal of International Law, 28, 1061-1062.

Webster, T. H., \& Buhler, M. (2014). Handbook of ICC Arbitration: Commentary, Precedents, Materials. London: Sweet \& Maxwell.

Wirth, M. (1999). Interim or Preventive Measures in Support of International Arbitration in Switzerland. ASA Bulletin, 18, 31-45.

Wong, J. (2004). The Issuance of Interim Measures in International Disputes: A Proposal Requiring a Reasonable Possibility of Success on the Merits. Georgia Journal of International \& Comparative Law, 33, 230.

\section{Law and Conventions}

1) ICC Rules of Arbitration 1994

2) Jordan Arbitration law 2018

3) Jordan Civil Procedures Law 2006

4) Malaysian Arbitration Act 2004

5) Singaporean Arbitration Act 1994

6) UNCITRAL Model Law 2012 